Tar. D is rare in W. Va., but in the Catskills the male of this is most abundant of all; the female much less so, being replaced by $\mathrm{C}$ and $\mathrm{B}$ to a great degree. Of 3 males, 3 females, sent me from New Hampshire by Mr. Whitncy, and taken at random from his collection, all were of the winter form, var. D, except I female of the summer form. From Canada, Labrador and Anticosti, all the examples received were D, with an occasional exception of var. C. Of 4 males from Colorado, all were D; of 2 females, I is D, I C. From Lake Lahache, Br. Columbia, lat. $54^{\circ}$, and perhaps the most northern limit of the species, I have I male D, I female C. From New Mexico even, taken high in the mountains, 2 males are decidedly of var. D, and similar to the usual type from Anticosti in markings, the under side also being like that, red-tinted.

(To be Continued.)

\title{
DESCRIPTION OF A NEW BOTIS ALLIED TO FLAVIDALIS.
}

\author{
BY A. R. GROTE,
}

Director of the Museum, Buffalo Society Natural Sciences.

I have received from Mr. Frank W. Langdon, of Madisonville, Ohio, a specimen ( 9 ) of a new species of Botis, which I name Botis Langdonalis after its discoverer. It is one of the largest and most striking forms yet made known, and belongs to the group of flavidalis, with which it agrees in the general color of body and wings. The fore wings from base to first transverse line are clouded with fuscous, and stained with ochreous. The two discal marks are present, the orbicular a dot, the reniform a streak. The space between the exterior transverse or elbowed line and the subterminal line is much wider than usual, and this space is filled in with a broad fuscous band crossing the hind wings as well ; the lines are only indicated by the contrast of color. An ocher discal dot on hind wings. Beyond the broad common band the terminal space is narrowly yellow on both wings. Beneath white, opalescent, with discal dots and the broad shade band repeated. Palpi white tipped with ferruginous ; body white beneath. Expanse 37 mil. Lensth of body I 8 mil. 